\title{
Genetic diversity of marine gastropods: contrasting strategies of Cerithium rupestre and $C$. scabridum in the Mediterranean Sea
}

\author{
Batia Lavie \& Eviatar Nevo \\ Institute of Evolution, University of Haifa, Mount Carmel, Haifa, Israel
}

\begin{abstract}
Allozymic variation encoded by 25 gene loci was compared and contrasted in natural coexisting populations of the marine gastropods Cerithium rupestre and $C$. scabridum collected along the rocky beach of the northern Mediterranean Sea of Israel. C. rupestre showed considerably less genic diversity than C. scabridum. Results support the niche-width variation hypothesis as C. scabridum may be considered a species characterized by a broader ecological niche than $C$. rupestre. However, the extreme difference between the genic diversity of the 2 species might result from at least 2 sets of factors reinforcing each other, namely the ecological niche as well as the life zone and life history characteristics.
\end{abstract}

\section{INTRODUCTION}

Since its first application for studies of genetic diversity, the technique of electrophoresis has been used in hundreds of surveys of natural populations. Nevo et al. (1984) analysed the genetic variability of 1111 species belonging to 10 higher taxa. The distribution patterns obtained for both genetic indices of diversity, heterozygosity $(H)$ and polymorphism $(P)$, showed striking heterogeneity among higher taxa. The lowest extremes of $H$ were generally exhibited by vertebrates, particularly by mammals, whereas the highest extremes of $H$ were displayed by invertebrates, particularly by molluscs. Nevertheless, there were significant differences between the heterozygosity of molluscs according to different habitat types. The highest mean heterozygosity was encountered in species living in the aquatic littoral habitat $(H=0.224)$, which comprises largely sedentary molluscs. But even the aquatic littoral can be partitioned into microniches and the genetic diversity of upper midlittoral species could be compared to species living in the lower midlittoral. Animals in the upper midlittoral are expected to be more tolerant to a larger range of ecological spectra including temperature, salinity, oxygen pressure and other factors affected by the distinct tidal fluctuations, thereby occupying a broader ecological niche.

According to the niche-width variation hypothesis
(Van Valen 1965) there should be a positive correlation between the niche breadth and the level of genetic diversity. Genetic-ecological correlations over many species demonstrate inferentially the adaptive significance of enzyme polymorphisms (see critical discussion in Nevo et al. 1984 and references therein), although exceptions have been found (e.g. Somero \& Soule' 1974). A test of the niche-width variation hypothesis previously conducted by us in the 3 Mediterranean littoral species of the family Trochidae: Monodonta turbinata, $M$. turbiformis and Gibbula richardi supported the hypothesis (Lavie \& Nevo 1981).

For a sound validation of the theory, however, many more such pair comparisons standardizing as much as possible both the taxonomy and ecology of the species tested and their life zones are necessary (Nevo 1978). Ritte \& Pashtan (1982) reported extremely high levels of genetic variability in 2 Cerithium species: $C$. caeruleum, a Red Sea species that did not colonize the Mediterranean Sea, and the colonizer species C. scabridum. Both showed $P=1.00$ and $H$ values higher than 0.6 .

The extreme level of polymorphism reported for Cerithium scabridum and the fact that a Mediterranean related species, namely C. rupestre, is sometimes encountered on the same site, make this pair a suitable candidate for retesting the niche-width variation hypothesis. Surveying the Mediterranean coasts of 
Israel, Ayal (1978) encountered C. scabridum more often in the upper midlittoral, whereas $C$. rupestre was found more often in the lower midlittoral. Along a $55 \mathrm{~m}$ transect perpendicular to the shoreline $C$. scabridum was consistently more abundant than $C$. rupestre across the first $42 \mathrm{~m}$. This section was characterized by higher salinity and temperature fluctuations than the lower portion of the transect where $C$. rupestre prevailed. Thus, we consider $C$. rupestre as a species with a narrower ecological niche than $C$. scabridum. Therefore, the niche-width variation hypothesis would predict a higher genetic diversity in C. scabridum. We present here evidence indicating that $C$. scabridum is indeed the more polymorphic and heterozygous of these 2 species.

\section{MATERIALS AND METHODS}

Species tested and sampling. The 2 cerithids involved in this study are Cerithium scabridum and $C$. rupestre. C. scabridum is a tropical species characterized by its extreme genetic diversity and abundance in the Red Sea. Since the opening of the Suez Canal, it has colonized the temperate Mediterranean and can now be found in large numbers along the coasts of Egypt, Israel, Lebanon, Syria, Gulf of Antalya (Turkey), and the east coast of Sicily (Barash \& Danin 1973, 1977). C. rupestre is a temperate species found in the Eastern Mediterranean (Egypt, Lebanon, Syria, Cyprus, Aegean Sea), Central and Western Mediterranean (Adriatic Sea, Western Basin - Northern and Central Areas, North Africa, Alboran Sea) and Eastern Atlantic (Spain, Portugal, Morocco, Madeira, Canary Isles) (Barash \& Danin 1983).

Our sampling sites along the northern Israeli coast, from south to north, include Caesarea, Haifa, Akko and Shavei-Zion. In each site both species were searched for, but only in Akko were both sampled together Al] the specimens were collected from rocky beaches on the same day either in autumn (Cerithium scabridum at Caesarea and Akko and C. rupestre at Haifa and Akko) or in spring (C. scabridum at Akko and ShaveiZion). Each sample included at least 46 specimens, kept in deep freoze at $-80^{\circ} \mathrm{C}$ until individual animal homogenates were lectrophoresed.

Electrophoretic technique. Allozymic variation of proteins encoded by 25 gene loci was studied by standard starch gel electrophoresis. The procedures used were those described by Yang in Selander et al. (1971). Seven buffer systems described by Lavie \& Nevo 1981 were used discontinuous Borate-Tris Citrate = Poulik; Tris-Citrate-EDTA, pH $8.0=$ TC $_{i}$ Borate-Tris $\mathrm{pH} 8.5=$ TRIS-HCl; Tris-Maleate-EDTA, $\mathrm{pH} 8.3=$ TM 8.3, pH 7.4 = TM 7.4; Tris-Borate-EDTA pH $8.0=$
TVB; discontinuous Lithium-Borate-Tris-Citrate, $\mathrm{pH}$ $8.4=\mathrm{LIOH}$. The buffer used for each enzyme is given in Table 1 When different buffers were used for the 2 species they are designated (s) for Cerithium scabridum and $(\mathrm{r})$ for $C$. rupestre.

Analysis of genetic diversity. The criteria used to measure the amount of genetic diversity were polymorphism ( $1 \%$ and $5 \%$ criterion) per population (P), heterozygosity per locus per individual $(H)$ and mean number of alleles per locus (A). Of the 27 loci tested, 23 were shared by both species, so that for each of them a comparison of $H$ and $A$ between the 2 species is feasible. In each species 1 of the remaining loci is monomorphic (IPO in Cerithium scabridum and $\mathrm{AO}$ in $C$. rupestre) and a second almost monomorphic (EST2 in $S$ scabridum and ACPH2 in C. rupestre).

\section{RESULTS}

Table 1 shows the number of alleles and heterozygosity for each locus in each population. The loci are presented in alphabetical order. Comparing the heterozygosity of Cerithium rupestre with that of $C$. scabridum from the same sampling site (Akko, autumn) the difference is noted $(+)$ when $C$. rupestre is less heterozygous as expected according to the nichewidth hypothesis. For $C$. rupestre from Haifa, the difference is noted $(+)$ only on those occasions when all populations of $C$. scabridum showed a higher value Even with these constraints, $C$. scabridum is genetically more variable than C. rupestre, as is evident from both the number of alleles and levels of heterozygosity Table 1 also provides data on $P$, the level of polymorphism. Again, C. scabridum is more polymorphic then $C$. rupestre for both the $5 \%$ and the $1 \%$ polymorphism criteria

The difference between the 2 species in the level of genetic diversity is so drastic that statistics seem unnecessary. Sign test (Siegel 1956), scoring (+) and (-) when comparing the number of alleles and heterozygosity, as well as the Bailey test for proportions (Bailey 1959), when comparing (P) values, rendered statistical significances much smaller than $p$ $=0.01$.

\section{DISCUSSION}

The most likely general mechanisms for maintaining genetic polymorphisms are spatially heterogeneous environments (Levene 1953, Bryant 1976, Hedrick et al. 1976, Gillespie 1978). Conditions for polymorphism in heterogeneous environments are less stringent than those of overdominant selection in multiple allelic systems, as also concluded by Lewontin et al. (1978). 
Table 1 Cerithium scabridum and C. rupestre. Number of alleles (A), polymorphism (P) and heterozygosity (H) per locus, for different populations

\begin{tabular}{|c|c|c|c|c|c|c|c|c|c|c|c|c|c|c|}
\hline \multirow[t]{3}{*}{ Lacus } & \multirow[t]{3}{*}{ Abbrev. } & \multirow[t]{3}{*}{ Buffer } & \multicolumn{12}{|c|}{ Population and season } \\
\hline & & & \multicolumn{2}{|c|}{$\begin{array}{c}C . \\
\text { scab- } \\
\text { nidum } \\
\text { Akko } \\
\text { (Spring) }\end{array}$} & \multicolumn{2}{|c|}{$\begin{array}{l}\text { C. scab- } \\
\text { ridum } \\
\text { Shavei } \\
\text { Zion } \\
\text { (Spring) }\end{array}$} & \multicolumn{2}{|c|}{$\begin{array}{c}C . \\
\text { scab- } \\
\text { ridum } \\
\text { Caesarea } \\
\text { (Autumn) }\end{array}$} & \multicolumn{2}{|c|}{$\begin{array}{c}\text { C. } \\
\text { scab- } \\
\text { ridum } \\
\text { Akko } \\
\text { (Autumn) }\end{array}$} & \multicolumn{2}{|c|}{$\begin{array}{c}\text { C. } \\
\text { rupestre } \\
\text { Akko } \\
\text { (Autumn) }\end{array}$} & \multicolumn{2}{|c|}{$\begin{array}{c}\text { C. } \\
\text { rupestre } \\
\text { Haifa } \\
\text { (Autumn) }\end{array}$} \\
\hline & & & A & $\mathrm{H}$ & A & $\mathrm{H}$ & $A$ & $\mathrm{H}$ & A & $\mathrm{H}$ & $A$ & $\mathrm{H}$ & $A$ & $\mathrm{H}$ \\
\hline \multirow[t]{2}{*}{ Aspartate amino transferase } & AAT 1 & Poulik & 3 & .20 & 3 & .07 & 3 & .07 & 3 & .11 & $1(+)$ & $.00(+)$ & $11+1$ & $.00(+)$ \\
\hline & AAT 2 & & 2 & .22 & 2 & .23 & 3 & .25 & 2 & .23 & $1(+)$ & $.00(+)$ & $11+)$ & $.00(+)$ \\
\hline Acid phosphate & $\begin{array}{l}\text { ACPH } 1 \\
\text { ACPH } 2\end{array}$ & $\mathrm{TC}$ & 4 & .30 & 4 & .39 & 4 & .54 & 3 & .20 & $\begin{array}{l}1(+) \\
1\end{array}$ & $\begin{array}{l}.00(+) \\
.00\end{array}$ & $\begin{array}{l}1(+) \\
2\end{array}$ & $\begin{array}{l}.00(+) \\
.05\end{array}$ \\
\hline Adenylate kinase & $\mathrm{AK}$ & TC & 2 & .09 & 2 & .05 & 2 & 12 & 3 & .16 & $2(+)$ & $.03(+)$ & 2 & $.03(+)$ \\
\hline \multirow[t]{2}{*}{ Alkaline phosphotase } & A.LP & TRIS- $\mathrm{HCl}(\mathrm{s})$ & & & & & & & & & & & & \\
\hline & & $\operatorname{TM} 7.4(\mathrm{r})$ & 3 & .28 & 3 & .24 & 3 & 37 & 4 & .22 & $3(+)$ & $.06(+)$ & 3 & $.05(+)$ \\
\hline \multirow{2}{*}{ Amino peptidase } & AP 1 & TRIS-HCl & 2 & .07 & 2 & .08 & 2 & .03 & 2 & .22 & $1(+)$ & $.00(+)$ & $1(+)$ & $.00(+)$ \\
\hline & AP 2 & & 1 & .00 & 1 & .00 & 1 & .00 & 1 & .00 & 1 & .00 & 1 & .00 \\
\hline Aldehyde oxidase & $\mathrm{AO}$ & TVB (r) & & & & & & & & & 1 & .00 & 1 & .00 \\
\hline Catalase & CAT & TRIS- $\mathrm{HCl}$ & 2 & .06 & 3 & .02 & 1 & .00 & 3 & .03 & $1(+)$ & $.00(+)$ & $2(-)$ & $.03(-)$ \\
\hline \multirow[t]{5}{*}{ Esterase } & EST 1 & TVB (I) & 4 & .19 & 3 & .33 & 3 & .23 & 3 & .04 & $1(+)$ & $.001+1$ & $1(+)$ & $.00(+)$ \\
\hline & EST 2 & TM7.5(s) & 2 & .00 & 2 & .02 & 1 & .00 & 2 & .03 & & & & \\
\hline & EST 3 & & 4 & .31 & 4 & 11 & 4 & .38 & 2 & .20 & $4(-)$ & $31(-)$ & $4(-)$ & $43(-)$ \\
\hline & EST 4 & & 4 & .52 & 3 & 38 & 3 & .31 & 4 & .40 & $3(t)$ & $10(+)$ & $3(+)$ & $13(+)$ \\
\hline & EST 5 & & 5 & .30 & 3 & 41 & 3 & 12 & 5 & .48 & $2(+)$ & $.06 i+1$ & $2(t)$ & $.03(+)$ \\
\hline Glycerate dehydrogenase & GLYDH & Poulik & 3 & .30 & 4 & 44 & 3 & .14 & 3 & .42 & $1(+)$ & $.00(+)$ & $1(+)$ & $.00(+)$ \\
\hline \multirow[t]{2}{*}{ General protein } & GP 1 & TM $8.3(r)$ & 1 & .00 & 1 & .00 & 1 & .00 & 2 & .06 & $1(+)$ & $.00(+)$ & 1 & .00 \\
\hline & GP 2 & $\mathrm{LIOH}(\mathrm{s})$ & 1 & .00 & 1 & .00 & 1 & .00 & 1 & .00 & 1 & .00 & 1 & .00 \\
\hline $\begin{array}{l}\text { Glucose-6-phosphate } \\
\text { dehydrogenase }\end{array}$ & G6PD & $\mathrm{TC}+$ & 3 & 0.9 & 1 & .00 & 3 & 17 & 3 & 30 & 3 & $10(+)$ & $2(-)$ & $15(-)$ \\
\hline Indophenol oxidase & IPO & $\mathrm{TC}(s)$ & 1 & .00 & 1 & .00 & 1 & .00 & 1 & .00 & & & & \\
\hline Lactate dehydrogenase & $\mathrm{LDH}$ & TRIS- $\mathrm{HCl}$ & 1 & .00 & 2 & .03 & 1 & .00 & 2 & .03 & $1(+)$ & $.001+1$ & 1 & $.00(+)$ \\
\hline Malate dehydrogenase & $\mathrm{MDH}$ & TVB (r) LJOH (s) & 2 & .23 & 3 & .08 & 2 & .15 & 3 & .50 & $1(+)$ & $.00(+)$ & $1(+)$ & $.00(+)$ \\
\hline Malic enzyme & ME & TM 8.3 & 3 & .03 & 2 & 13 & 3 & .25 & 3 & 14 & $2(+)$ & $.05(t)$ & $1(+)$ & $.00(+)$ \\
\hline Naphtol dehydrogenase & NADH & $\mathrm{LIOH}$ & 2 & .15 & 2 & .07 & 2 & .10 & 2 & 12 & $1(+)$ & $.00(+)$ & & $.03 i+1$ \\
\hline Phosphoglucose isomerase & PGI & Poulik & 2 & .14 & 3 & .22 & 3 & .31 & 3 & .09 & $1(+)$ & $.00(+)$ & $1(+)$ & $.00(+)$ \\
\hline \multirow{2}{*}{ Phosphoglucomutase } & PGM 1 & TM $7.4(s)$ & 4 & .32 & 4 & .30 & 3 & .16 & 4 & .45 & $1(+)$ & $.00 i+1$ & $1(+)$ & $.00(+)$ \\
\hline & PGM 2 & & 3 & .33 & 3 & 38 & 3 & 26 & 3 & .25 & $2(+)$ & $.09(+)$ & $2(+)$ & $.04(+)$ \\
\hline \multirow{3}{*}{\multicolumn{2}{|c|}{$\begin{array}{l}\text { Mean } A \text { and } \mathrm{H} \\
\mathrm{P} \text {, criterion } 5 \% \\
\text { criterion } 1 \%\end{array}$}} & & \multicolumn{2}{|c|}{$2.48 \quad 17$} & \multicolumn{2}{|c|}{2.52 .12} & \multicolumn{2}{|c|}{$2.32 \quad 19$} & \multicolumn{2}{|c|}{$2.68 \quad 19$} & \multicolumn{2}{|c|}{$1.48 \quad .03$} & \multicolumn{2}{|c|}{$1.52 \quad .04$} \\
\hline & & & \multicolumn{2}{|c|}{.76} & & 76 & 7 & 2 & & 76 & & 20 & & 20 \\
\hline & & & & 30 & $\varepsilon$ & 80 & .7 & 2 & & 84 & & .32 & & .32 \\
\hline
\end{tabular}

The idea of positive correlation between genetic and environmental variation, the niche-width variation hypothesis (Van Valen 1965), is widespread in evolutionary biology (e. g. Levene 1953, Levins 1968). It was critically tested and confirmed for karyotypic, and suggested for electrophoretic (Powell 1971, McDonald \& Ayala 1974, Powell \& Wistrand 1978), as well as for quantitative traits (Mackay 1981 and references therein).

The prediction of the environmental amplitude hypothesis was refuted in some marine organisms, i. e. fishes (Somero \& Soule' 1974), and other organisms such as invertebrates (Schopf \& Gooch 1971, Ayala \& Valentine 1979), butterflies (Mitter \& Futuyma 1979) and mice (Smith 1981), but has been confirmed on several occasions, such as in restricted and widespread plant species (Babbel \& Selander 1975), Drosophila (Beardmore 1961, Long 1970, Powell 1971, McDonald
\& Ayala 1974, Steiner 1977, Powell \& Witstrand 1978, Mackay 1980, Lacy 1982), fishes (Avise \& Selander 1972, Narang 1980), frogs (Nevo 1976), salamanders (Karlin \& Guttman 1981) and molluscs (Wilkins 1975. Lavie \& Nevo 1981). Finally, statistical analysis of 1111 species indicates that genetic diversity is higher in species living in broader environmental spectra, again supporting on a larger statistical scale the niche-width variation hypothesis, despite the known counter examples (Nevo et al. 1984).

In none of the above quoted individual studies is the difference in genetic variability between the species studied so extreme as in the species pair Cerithium scabridum and C. rupestre. Even though in our study the values obtained for C. scabridum are not as high as reported by Ritte \& Pashtan (1982), C. scabridum is above average, while $C$. rupestre is below the average value, presented by Nevo et al. 1984, for Mollusca 
(mean $H=0.148$; mean $P=0.468 ; \mathrm{N}=46$ species). The magnitude of the difference is so extreme that we were compelled to look for additional forces causing such a low level of genetic diversity in C. rupestre. And indeed, besides the differences in niche-width, the observed species differ drastically in their life histories. Ayal (1978) presented C. scabridum as an $r$ selected species while $C$. rupestre demonstrated $k$ selection strategy. Among the most outstanding differences between the 2 species are the life cycle and fecundity rates. C. rupestre does not have a long-lived pelagic larva as does C. scabridum, but hatches from eggs oviposited on algae. Furthermore, the rate of eggs laid per day per female is 15 to 80 for C. rupestre and 1500 to 3000 for $C$. scabridum. This indicates higher dispersal of young and higher fecundity for C. scabridum.

According to the data reviewed by Nevo et al. (1984) for 36 mollusc species, heterozygosity is significantly higher for species with high as compared to species with low dispersal of young $(H=0.295$ versus $H=$ 0.075 , respectively, $\mathrm{P}<0.01$ ). Likewise, heterozygosity in mollusc species with fecundity values higher than 1000 is significantly higher than in species with low fecundity $(H=0.412$ versus $H=0.094$, respectively, P $<0.001$ ). The combination of $r$-strategy and high genic diversity may have contributed to the distinct colonizing ability of Cerithium scabridum from the Red Sea to the Mediterranean Sea (Safriel \& Ritte 1983).

It is interesting to note that the only species of marine gastropods for which very high polymorphism was reported $(P=1.00)$ are Cerithium caeruleum and C. scabridum (Ritte \& Pashtan 1982); 2 additional intertidal cerithid species from the Red Sea, Clypeomorus tuberculatum and Clypeomorus moniliferum (Noy 1983); an inter-tidal clam from the Red Sea, Modiolus auriculatus (Lavee 1983); and another intertidal gastropod, the limpet Collisella digitalis, which is distributed throughout the temperate provinces of Japan and North-America (Gresham \& Tracey 1975). In all the above mentioned species, the major determinants of the level of diversity may include at least 2 factors associated with their specific life histories, namely a very high rate of reproduction and dispersal ability. All are intertidal gastropods with long-lived pelagic larvae. Therefore, the extreme difference between the levels of genetic diversity in C. scabridum and in $C$. rupestre may be due to their combined differences in niche-width, as well as in life histories. Notably, however, life history and ecological niche are not unrelated. Nymberg (1974), for example, reported larger niche size of the more outbreeding ciliates. Finally, the levels of heterozygosity differ significantly in species living in different life zones (Nevo et al. 1984). This is true for all species tested, as well as for molluscs, where tropical species harbour significantly more genic diversity as compared with temperate species ( $H$ $=0.205$ versus 0.071 , respectively; $p<0.001$ )

The evidence presented here suggests that the characteristics of the niche and life zone are reinforced by demographic (i. e. dispersal) and life history (i. e. fecundity) factors in shaping the levels of genetic diversity. The analysis of genic diversity appears to indicate that multiple factors affect the levels of heterozygosity and polymorphism in natural populations. The relative importance of the various cooperating factors may be approximated by standardizing as far as possible the species compared in many relevant factors and restricting the test to a major differentiating variable.

Acknowledgements. We thank Ruth Baker for field and laboratory assistance. This research was partly supported by grant from FAO/UNEP, and the Israel Discount Bank Chair of Evolutionary Biology at the Institute of Evolution, University of Haifa.

\section{LITERATURE CITED}

Avise, J. C., Selander, R. K. (1972). Evolutionary genetics of cave-dwelling fishes of the genus Astyanax. Evolution 26: $1-19$

Ayal, Y (1978). Geographical distribution, ecological niche and the strategy of reproduction of the colonizer Cerithium scabridum Phil. (Gast: Cerithidae) as compared with those of some other sympatric non-colonizing congeneric species. Ph. D. thesis, Hebrew Univ. of Jerusalem

Ayala, F. J., Valentine, J. W. (1979). Genetic variability in the pelagic environment: A paradox? Ecology 60: 24-29

Babbel, G. R., Selander, R. K. (1975). Genetic variability in edaphically restricted and wide-spread plant species. Evolution 28: 619-630

Barash, A., Danin, Z. (1973). The Indo-Pacific species of Mollusca in the Mediterranean and notes on a collection from the Suez Canal. Israel J. Zool. 21. 301-374

Barash, A., Danin, Z. (1977). Addition to the knowledge of Indo Pacific Mollusca in the Mediterranean. Conchiglie, Milano 13: 85-116

Barash, A., Danin, Z. (1983). Annotated list of the Mediterranean Mollusca of Israel and Sinai. Fauna Palestina Committee of the Israel Academy of Sciences and Humanities

Beardmore, J. A. (1961). Diurnal temperature fluctation and genetic variance in Drosophila populations. Nature, Lond. 189: $162-163$

Bailey, N. J. J. (1959). Statistical methods in biology. English University Press, London, p. 38-39

Bryant. E. H. (1976). A comment on the role of environmental variation in maintaining polymorphisms in natural popuIations. Evolution 30: 188-190

Gillespie, J. H. (1978). A general model to account for enzyme variation in natural populations. $V$ The SAS-CFF model. Theor Populat. Biol. 14: 1-45

Gresham, M. L. Tracey, M. L. (1975). Genetic variation in an intertidal gastropod, Collisella digitalis. Genetics 80: 37

Hedrick, P. W., Ginevan, M. E., Ewing, E. P. (1976) Genetic polymorphism in heterogenous environments. A. Rev. Ecol. Syst. 7: 1-32

Karlin, A. A., Guttman, S. I. (1981). Hybridization between Desmognathus fuscus and Desmognathus ochrophaeus 
(Amphibia: Urodella: Plethodontidae) in Northeastern Ohio and Northwestern Pennsylvania. Copeia 1981: $371-377$

Lacy, R. C. (1982). Niche breadth and abundance as determinants of genetic variation in populations of mysophagous Drosophilid flies (Diptera: Drosophilidae). Evolution 36: 1265-1275

Lavee, D. (1983): Genetic variability and colonization in two species of Indopacific mussels. Ph. D. thesis, Hebrew Univ. of Jerusalem

Lavie, B., Nevo, E. (1981). Genetic diversity in marine molluscs: A test of the niche-width variation hypothesis. P.S.Z.N. Mar. Ecol. 2: 335-342

Levene, H. (1953). Genetic equilibrium when more than one ecological niche is available. Am. Nat. 87: 331-333

Levins, R. (1968). Evolution in changing environments. Princeton University, Princeton, New Jersey

Lewontin, R. C., Ginzburg, L. R., Tuljapurkar, S. D. (1978). Heterosis as an explanation for large amounts of genic polymorphism. Genetics 88: 149-169

Long, T (1970). Genetic effects of fluctuating temperature in populations of Drosophila melanogaster. Genetics 66: $401-416$

Mackay, T F. C. (1980). Genetic variance, fitness and homeostasis in varying environments: An experimental check on the theory. Evolution 34: 1219-1222

Mackay, T F. C. (1981): Genetic variation in varying environments. Genet. Res. 37: 79-93

McDonald, J. F., Ayala, F. J. (1974). Genetic response to environmental heterogeneity. Nature, Lond. 250: 572-574

Mitter, C., Futuyma, D. J. (1979). Population genetic consequences of feeding habits in some forest Lepidoptera. Genetics 92: 1005-1021

Narang, S. (1980). Genetic variability in natural populations, evidence in support of the selectionist view. Experientia 36: $50-51$

Nevo, E. (1976): Adaptive strategies of genetic systems in constant and varying environments, In: Karlin, S., Nevo, E. (ed.) Population genetics and ecology. Academic Press, New York, p. 141-158

Nevo, E. (1978). Genetic variation in natural populations: pattern and theory. Theor. Populat. Biol. 13: 121-177

Nevo, E., Beiles, A., Ben-Shlomo, R. (1984). The evolutionary significance of genetic diversity: ecological, demographic and life history correlates. In: Mani, G. S. (ed.) Evolutio- nary dynamics of genetic diversity. Lecture notes in biomathematics 53: 13-213

Noy, R. (1983). Environmental heterogeneity and electrophoretic variability in three inter-tidal cerithid species (Mollusca: Gastropoda) from the Red Sea M. Sc. thesis, Hebrew Univ. of Jerusalem

Nymberg, D. (1974). Breeding system and resistance to environmental stress in ciliates. Evolution 28: 367-380

Powell, J. R. (1971). Genetic polymorphism in varied environments. Science 174: 1035-1036

Powell, J. R., Wistrand, H. (1978). The effect of heterogeneous environments and a competitor on genetic variation in Drosophila. Am. Nat. 112: 935-947

Ritte, U., Pashtan, A. (1982). Extreme levels of genetic variability in two Red Sea Cerithium species (Gastropoda: Cerithidae). Evolution 36: 403-407

Safriel, N. U., Ritte, U. (1983). Universal correlates of colonizing ability. In: Swingland, I. R., Greenwood, R. T. (ed.) The ecology of animal movement. Clarendon Press. Oxford, p. 215-239.

Schopf, T J., Gooch, J. L. (1971). A natural experiment using deep-sea invertebrates to test the hypothesis that genetic homozygosity is proportional to environmental stability. Biol, Bull mar. biol. Lab., Wood Hole 141: 401

Selander, R. K., Smith, H. M., Yang, S. Y., Johnson, W E., Gentry, G. B. (1971). Biochemical polymorphism and systematics in the genus Peromyscus. Variation in the old field mouse (Peromyscus polionatus). Univ. Tex. Publ. 7103: 49-90

Siegel, S. (1956). Nonparametric statistics for the behavioral sciences. McGraw Hill, New York

Smith, M. F. (1981). Relationship between genetic variability and niche dimensions among coexisting species of Peromyscus. J. Mammal. 62: 273-285

Somero, G. N., Soule', M. (1974). Genetic variation in marine fishes as a test of the niche-variation hypothesis. Nature, Lond. 249: 670-672

Steiner W. W. M. (1977). Niche width and genetic variation in Hawaiian Drosophila. Am. Nat. 111: 1037-1046

Van Valen, L. (1965): Morphological variation and width of ecological niche. Am. Nat. 99: 377-390

Wilkins, N. P. (1975). Phosphoglucose isomerase in marine molluscs. In: Market, C. L. (ed.) Isozymes, genetics and evolution, Vol. 4. Academic Press, New York, p. 931-943 